\title{
Erratum: Measuring autistic traits in the general population: a systematic review of the Autism-Spectrum Quotient (AQ) in a nonclinical population sample of 6,900 typical adult males and females
}

\author{
Emily Ruzich ${ }^{1,2^{*}}$, Carrie Allison ${ }^{2}$, Paula Smith², Peter Watson ${ }^{3}$, Bonnie Auyeung ${ }^{2,4}$, Howard Ring ${ }^{1,5,6}$ \\ and Simon Baron-Cohen ${ }^{2,5,7}$
}

\section{Erratum}

A correction should be made to the confidence intervals stated in the abstract, as they do not reflect those reported in the manuscript body. It was stated that "Mean AQ score for the nonclinical population was 16.94 (95 \% CI 11.6, 20.0), while mean $A Q$ score for the clinical population with ASC was found to be 35.19 (95\% CI 27.6, 41.1)." In fact, the first set of confidence intervals should read (95\% CI 16.4, 17.4) for the nonclinical sample, and the second should read (95\% CI 34.5, 35.9) for those with ASC.

\section{Author details}

${ }^{1}$ Cambridge Intellectual and Developmental Disabilities Research Group, Department of Psychiatry, University of Cambridge, Douglas House, 18B Trumpington Road, CB2 8AH Cambridge, UK. ${ }^{2}$ Autism Research Centre, Department of Psychiatry, University of Cambridge, Douglas House, 18B Trumpington Road, Cambridge CB2 8AH, UK. ${ }^{3}$ MRC Cognition and Brain Sciences Unit, 15 Chaucer Road, Cambridge CB2 7EF, UK. ${ }^{4}$ Psychology Department, University of Edinburgh, 3 Charles Street, Edinburgh EH8 9AD, UK. ${ }^{5} \mathrm{NIHR}$ CLAHRC for the East of England, Douglas House, 18B Trumpington Road, Cambridge CB2 8AH, England, UK. ${ }^{6}$ Cambridgeshire and Peterborough NHS Foundation Trust, Peterborough CB21 5EF, UK. ${ }^{7}$ CLASS Clinic, Cambridgeshire and Peterborough NHS Foundation Trust, Peterborough CB21 5EF, UK.

\footnotetext{
* Correspondence: emr37@cam.ac.uk

${ }^{1}$ Cambridge Intellectual and Developmental Disabilities Research Group, Department of Psychiatry, University of Cambridge, Douglas House, 18B Trumpington Road, CB2 8AH Cambridge, UK

${ }^{2}$ Autism Research Centre, Department of Psychiatry, University of Cambridge, Douglas House, 18B Trumpington Road, Cambridge CB2 8AH, UK
}

Received: 3 July 2015 Accepted: 3 July 2015

Published online: 12 August 2015

\section{References}

1. Ruzich E, Allison C, Smith P, Watson P, Auyeung B, Ring H, et al.

Measuring autistic traits in the general population: a systematic review of the Autism-Spectrum Quotient (AQ) in a nonclinical population sample of 6,900 typical adult males and females. Mol Autism. 2015;6:2.

\section{Submit your next manuscript to BioMed Central and take full advantage of:}

- Convenient online submission

- Thorough peer review

- No space constraints or color figure charges

- Immediate publication on acceptance

- Inclusion in PubMed, CAS, Scopus and Google Scholar

- Research which is freely available for redistribution 